\title{
Peran Pemangku Kepentingan dalam Pengembangan Klaster Enceng Gondok di Kecamatan Banyubiru
}

\author{
Dwi Lestari ${ }^{1}$ \\ Departemen Perencanaan Wilayah dan Kota, Fakultas Teknik \\ Universitas Diponegoro, Semarang, Indonesia

\section{Mohammad Muktiali} \\ Departemen Perencanaan Wilayah dan Kota, Fakultas Teknik \\ Universitas Diponegoro, Semarang, Indonesia
}

Artikel Masuk : 7 April 2017

Artikel Diterima : 7 September 2017

Tersedia Online : 29 Desember 2017

\begin{abstract}
Abstrak: Pengembangan ekonomi lokal (PEL) merupakan salah satu konsep pengembangan wilayah yang menekankan pada penggunaan sumber daya dan kemampuan-kemampuan lokal serta kerja sama di antara seluruh komponen untuk mewujudkan pembangunan yang berkualitas dan berkelanjutan. Salah satu upaya dalam pengembangan ekonomi lokal di suatu daerah dapat dilakukan melalui pendekatan klaster usaha (industri). Klaster merupakan pengelompokkan usaha yang memiliki karakteristik kesamaan sektor usaha dan kedekatan wilayah. Dalam perkembangannya, agar dapat tumbuh dengan baik dibutuhkan peran dan keterlibatan dari seluruh pemangku kepentingan untuk mendorong kemajuan klaster. Pemangku kepentingan ini tidak hanya pemerintah daerah, tetapi juga sektor swasta yang mencakup lembaga pembiayaan, lembaga non pemerintah, lembaga pendidikan serta masyarakat lokal. Klaster Enceng Gondok di Kecamatan Banyubiru merupakan salah satu klaster unggulan yang berkembang di Kabupaten Semarang. Dalam pengembangannya, Klaster Enceng Gondok menghadapi beberapa permasalahan yang menghambat kemajuan klaster. Untuk mengatasi permasalahan klaster, terdapat beberapa pemangku kepentingan yang terlibat dan memiliki peran tertentu di dalam klaster. Penelitian ini bertujuan untuk memahami dan mengukur efektivitas peran yang dilakukan masing-masing pemangku kepentingan dalam pengembangan klaster eceng gondok di Kecamatan Banyubiru. Penelitian ini menggunakan metode penelitian mix-method yang menggabungkan antara penelitian kuantitatif dan kualitatif. Pendekatan kuantitatif digunakan untuk mengukur efektivitas dari peran yang dilakukan pemangku kepentingan yang terlibat dalam klaster, sedangkan pendekatan kualitatif digunakan untuk mengkaji dan memahami peran pemangku kepentingan secara lebih mendalam. Dari hasil analisis dan temuan penelitian dapat diperoleh kesimpulan mengenai peranan yang dilakukan masing-masing pemangku kepentingan dalam pengembangan Klaster Enceng Gondok di Kecamatan Banyubiru. Sesuai dengan hasil penelitian diketahui bahwa lembaga nonpemerintah memiliki keterlibatan yang paling dominan dibandingkan pemangku kepentingan lainnya dan dari keseluruhan peranan yang
\end{abstract}

\footnotetext{
${ }^{1}$ Korespondensi Penulis: Departemen Perencanaan Wilayah dan Kota, Fakultas Teknik

Universitas Diponegoro, Semarang, Indonesia

Email: dwi16lestari@gmail.com
} 
telah dilakukan pemangku kepentingan dalam Klaster Enceng Gondok, peranan dalam tahap input produksi merupakan peranan yang dinilai sangat efektif bagi klaster.

Kata kunci: kerajinan enceng gondok, klaster industri, pemangku kepentingan, pengembangan klaster

\begin{abstract}
Local economic development (LED) is part of regional development concepts which emphasizes the use of local resources and capabilities and cooperation between all components to achieve quality and sustainable development. The LED initiatives could be accomplished through (industrial) business cluster approach. Cluster is basically a grouping of businesses characterized by business commonalities in proximate locations. The cluster growth requires proper role and involvement from the all stakeholders ranging from public to private sectors such as financial institutions, non-governmental organizations, educational institutions and local communities. Water Hyacinth Cluster in Banyubiru Subdistrict of Semarang Regency is of a good example. During its development trajectories, the Water Hyacinth Cluster has faced several problems because of which the call upon multiple stakeholders involvement necessary. This study aims to figure out and measure the effectiveness of the role played by each stakeholder in the observed cluster development. This study uses a mixed method research which combines quantitative and qualitative approaches. The quantitative approach is used to measure the effectiveness of the role played by the stakeholders involved in cluster, and the qualitative approach to assess and figure out the role of stakeholders deeper. The conclusion reveals that the non-government institutions perform the most dominant involvement among the remaining stakeholders. In addition, the role in production input stage is considerably more effective to the overall cluster performance.
\end{abstract}

Keywords: cluster development, industry cluster, stakeholder, water hyacinth handicraft

\title{
Pendahuluan
}

Untuk menghadapi tantangan dan permasalahan ekonomi di era pasca krisis ekonomi dan globalisasi ini, kebijakan dalam pengembangan wilayah perlu lebih berorientasi kepada pengembangan ekonomi lokal (PEL) untuk mempercepat pembangunan ekonomi di daerah. PEL dianggap sebagai salah satu pendekatan yang sesuai untuk diterapkan di Indonesia dan dianggap mampu mengatasi berbagai persoalan karena bersifat holistik atau menyeluruh (Rahma, 2012). Salah satu bentuk pengembangan ekonomi lokal di Indonesia adalah melalui pengembangan klaster. Klaster merupakan sekelompok usaha yang tergabung bersama secara geografis yang memiliki keterkaitan sinergis dan ditunjang, serta didukung dengan institusi dan aktivitas penunjang usaha sehingga terbentuk rantai nilai yang menghasilkan efisiensi kolektif (Schmitz, 1995). Klaster memiliki peranan penting dalam pembangunan dan perkembangan ekonomi lokal suatu daerah. Namun dalam pelaksanaannya, konsep klaster untuk pengembangan ekonomi suatu daerah masih sulit diterapkan karena kondisi sebagian besar klaster di Indonesia masih memiliki daya saing yang rendah. Sumodiningrat (2000) menyebutkan bahwa klaster yang harus dikembangkan oleh suatu daerah, setidaknya harus memiliki ciri-ciri (source of advantage), yang meliputi: keunggulan komparatif (comparative advantage), keunggulan kompetitif (competitive advantage), dan keunggulan institusional (institutional advantage).

Pengembangan ekonomi melalui strategi klaster dengan pengelompokan kegiatan ekonomi pada suatu daerah dianggap menjadi salah satu cara yang efektif untuk mendorong pengembangan usaha dan pertumbuhan ekonomi lokal. Pengembangan klaster dapat dilakukan dengan pendekatan pengembangan rantai nilai usaha yang dapat memberikan nilai tambah dan meningkatkan kinerja pelaku usaha dalam klaster (Herr \& Muzira, 2009). Kaplinsky \& Morris (2004) mendefinisikan rantai nilai sebagai serangkaian 
kegiatan yang dilakukan dalam mengimplementasikan produk/jasa mulai dari konsep, tahap produksi hingga pemasaran ke konsumen akhir secara lengkap termasuk seluruh pelaku ekonomi yang terlibat dalam pembuatan suatu produk.

Pada dasarnya pengembangan klaster berpusat pada pengembangan kegiatan inti usaha yang berlangsung di dalamnya mulai dari pengadaan bahan baku hingga pemasaran. Aliansi atau kerja sama yang terjalin dalam sistem produksi menjadi salah satu aspek penting untuk meningkatkan nilai tambah rantai usaha klaster (Schmitz, 1999). Keberhasilan pengembangan suatu klaster di daerah tidak terlepas dari peran seluruh pemangku kepentingan yang terlibat. Pemangku kepentingan yang dimaksud tidak hanya mengarah pada pemerintah daerah saja tetapi juga seluruh pemangku kepentingan terkait, termasuk sektor swasta (perbankan), lembaga nonpemerintah maupun perguruan tinggi. Dalam praktiknya, banyak klaster PEL di sejumlah daerah di Indonesia berhasil berkembang secara alami tanpa banyak intervensi dari pemerintah. Namun sejumlah klaster lainnya berhasil tumbuh dan berkembang dengan baik dengan dukungan dan intervensi dari pemerintah (Rahma, 2012). Dukungan dari pemerintah yang besar dibutuhkan oleh pelaku usaha klaster mengingat adanya keterbatasan-keterbatasan pelaku usaha dalam sistem produksi (rantai nilai usaha) yang dapat mempengaruhi keberlanjutan usaha yang dijalankan (Rinaldy, 2007). Pada dasarnya banyak faktor yang secara tunggal ataupun berkombinasi dapat mempengaruhi keberhasilan pengembangan klaster PEL di daerah, termasuk peran dan intervensi dari seluruh pemangku kepentingan (Djamhari, 2006). Selain itu keberadaan penggerak klaster seperti koperasi, perusahaan besar, asosiasi LSM, lembaga penelitian serta perguruan tinggi juga menjadi pelaku penting yang memiliki andil dalam mendorong pengembangan klaster (Bank Indonesia, 2015).

Klaster Enceng Gondok di Kecamatan Banyubiru merupakan salah satu klaster unggulan yang berkembang di wilayah Kabupaten Semarang. Untuk mendorong pengembangan Klaster Enceng Gondok, salah satu hal yang perlu diperhatikan adalah bagaimana mengatasi berbagai permasalahan yang terjadi di dalam klaster (Retnoningrum, 2011). Dalam Klaster Enceng Gondok terdapat beberapa pemangku kepentingan yang turut terlibat mulai dari pemerintah, lembaga pembiayaan (perbankan), lembaga nonpemerintah, serta lembaga pendidikan dan penelitian (perguruan tinggi). Untuk mendorong pertumbuhan klaster yang efektif maka pendekatan yang digunakan dalam melakukan intervensi dalam klaster salah satunya harus berorientasi pada kolektivitas (Humphrey \& Schmitz, 1996). Dalam pelaksanaan perannya, beberapa pemangku kepentingan menjalin kerja sama dalam memberikan bantuan dan dukungan bagi pelaku usaha dalam bentuk kegiatan pelatihan-pelatihan serta pendampingan yang berfokus pada pengembangan inti usaha klaster termasuk memberikan solusi terhadap permasalahan yang dihadapi klaster. Adanya kerja sama di antara pemangku kepentingan diharapkan dapat memberikan manfaat yang berarti tidak hanya manfaat ekonomi, tetapi juga manfaat teknis maupun manfaat sosial khususnya bagi masyarakat lokal (Ginting \& Prabatmodjo, 2015). Adanya berbagai pemangku kepentingan yang terlibat dalam Klaster Enceng Gondok perlu dikaji untuk mengetahui bagaimana peranan dan efektivitas peran yang dilakukan masing-masing dalam pengembangan inti usaha (sistem produksi) klaster terutama dalam mengatasi berbagai permasalahan yang terjadi di sistem produksi dalam Klaster Enceng Gondok.

\section{Metode Penelitian}

Penelitian ini bertujuan untuk mengkaji bagaimana peranan yang dilakukan pemangku kepentingan dalam pengembangan klaster serta mengukur efektivitas dari peranan yang dilakukan masing-masing pemangku kepentingan dalam pengembangan Klaster Enceng Gondok di Kecamatan Banyubiru. Penelitian ini menggunakan pendekatan penelitian mix-method (campuran) yang menggabungkan antara metode penelitian kuantitatif dan kualitatif untuk memperoleh data dan hasil yang lebih komprehensif, 


\section{Peran Pemangku Kepentingan dalam Pengembangan Klaster...}

reliabel, valid dan objektif (Sugiyono, 2015). Pemilihan pendekatan penelitian mix-method (campuran) dalam penelitian yang dilakukan karena penelitian ini bertujuan untuk memahami bagaimana peranan yang dilakukan pemangku kepentingan yang terlibat dalam Klaster Enceng Gondok di Kecamatan Banyubiru, untuk selanjutnya dinilai bagaimana efektivitas peran yang dilakukan masing-masing pemangku kepentingan berdasarkan persepsi pelaku usaha (pengrajin) dalam klaster.

Pendekatan mix-method dalam penelitian ini menggunakan strategi triangulasi konkuren sehingga pengumpulan data kuantitatif dan kualitatif dilakukan oleh peneliti dalam satu waktu (konkuren), kemudian membandingkan hasil yang diperoleh untuk mengetahui apakah terdapat perbedaan, konvergensi ataupun kombinasi. Penggunaan strategi ini dimaksudkan untuk menutupi kekurangan yang dimiliki satu metode dengan kelebihan pada metode lain atau sebaliknya sehingga dapat melengkapi data dan analisis secara lebih komprehensif (Creswell, 2010). Jenis data yang diperlukan dalam penelitian ini terdiri dari data kuantitatif dan data kualitatif. Data tersebut diperoleh melalui survei primer dengan melakukan wawancara terstruktur dan kuesioner. Pengambilan sampel dalam penelitian menggunakan teknik nonprobability sampling dengan cara purposive sampling sehingga diperoleh jumlah sampel sebanyak 68 responden. Adapun teknik analisis yang digunakan dalam penelitian ini adalah analisis deskriptif dan analisis skoring. Analisis deskriptif digunakan untuk mendeskripsikan, menguraikan atau menjelaskan hasil dari kompilasi data. Adapun analisis skoring bertujuan untuk memberikan skor atau nilai terhadap objek penelitian berdasarkan kriteria tertentu. Untuk mengukur efektivitas peran pemangku kepentingan dalam pengembangan klaster, maka dilakukan pengumpulan data melalui kuesioner dengan menggunakan skala likert sebagai metode penilaiannya. Penilaian efektivitas peran pemangku kepentingan dalam pengembangan, dibagi menjadi tiga kategori penilaian yakni: kurang efektif (nilai $=1$ ), cukup efektif (nilai $=2$ ) dan sangat efektif (nilai $=3$ ). Hasil total dari penilaian tersebut selanjutnya digunakan sebagai pedoman dalam menentukan klasifikasi.

Tabel 1. Kriteria Penilaian Efektivitas Pemangku Kepentingan dalam Masing-masing Perannya

\begin{tabular}{cl}
\hline Range Nilai & \multicolumn{1}{c}{ Keterangan } \\
\hline$<68$ & $\begin{array}{l}\text { Pemangku kepentingan dalam menjalankan perannya dinilai kurang efektif } \\
\text { bagi klaster }\end{array}$ \\
$68<$ nilai $\leq 136$ & $\begin{array}{l}\text { Pemangku kepentingan dalam menjalankan perannya dinilai cukup efektif bagi } \\
\text { klaster }\end{array}$ \\
$136<$ nilai $\leq 204$ & $\begin{array}{l}\text { Pemangku kepentingan dalam menjalankan perannya dinilai sangat efektif } \\
\text { bagi klaster }\end{array}$ \\
\hline Sumber : Analisis Penyusun, 2016
\end{tabular}

Tabel 2. Kriteria Penilaian Efektivitas Seluruh Pemangku kepentingan

\begin{tabular}{cl}
\hline \multicolumn{1}{c}{ Range nilai } & \multicolumn{1}{c}{ Keterangan } \\
\hline$<2312$ & $\begin{array}{l}\text { Peran pemangku kepentingan dinilai kurang efektif bagi } \\
\text { klaster }\end{array}$ \\
$2312<$ nilai $\leq 4624$ & $\begin{array}{l}\text { Peran pemangku kepentingan dinilai cukup efektif bagi } \\
\text { klaster } \\
4624<\text { nilai } \leq 6936\end{array}$ \\
$\begin{array}{l}\text { Peran pemangku kepentingan dinilai sangat efektif bagi } \\
\text { klaster }\end{array}$ \\
\hline Sumber : Analisis Penyusun, 2016
\end{tabular}




\section{Analisis Peran Pemangku Kepentingan dalam Pengembangan Klaster Enceng Gondok}

Analisis pemangku kepentingan dilakukan untuk mengetahui peran dan fungsi dari masing-masing pemangku kepentingan yang terlibat atau ikut berpengaruh terhadap implementasi suatu kebijakan, keputusan atau tindakan dari suatu program berdasarkan tingkat pengaruh (influence) dan kekuatan (power) atau kepentingan (interest) (Oktavia \& Saharuddin, 2013). Dalam analisis ini akan dilihat bagaimana peran masing-masing pemangku kepentingan dalam pengembangan kegiatan inti usaha klaster, yaitu berupa kegiatan atau pendampingan yang dilakukan/diberikan oleh masing-masing pemangku kepentingan terutama dalam mengatasi permasalahan yang terjadi di dalam klaster, serta seberapa besar pengaruh dari peran pemangku kepentingan yang telah dilakukan terhadap klaster usaha kerajinan enceng gondok di Kecamatan Banyubiru, Kabupaten Semarang. Peran yang dilakukan masing-masing pemangku kepentingan dalam klaster dibedakan ke dalam peran dalam input produksi, proses produksi, output produksi serta pemasaran.

\section{Pemangku Kepentingan dalam Klaster Enceng Gondok}

Menurut Hornby (1995), pemangku kepentingan dapat didefinisikan sebagai perorangan, sekelompok orang atau organisasi dan sejenisnya yang dianggap memiliki peran atau andil dalam kegiatan suatu usaha, bisnis atau industri. Dalam menjalankan usahanya, pengrajin pada Klaster Enceng Gondok memperoleh bantuan dan dukungan dari beberapa pemangku kepentingan yang dapat dikategorikan ke dalam empat kelompok yakni kelompok pemerintah (kabupaten dan provinsi), lembaga nonpemerintah (lembaga donor/LSM), lembaga pembiayaan (perbankan) serta lembaga pendidikan (perguruan tinggi).

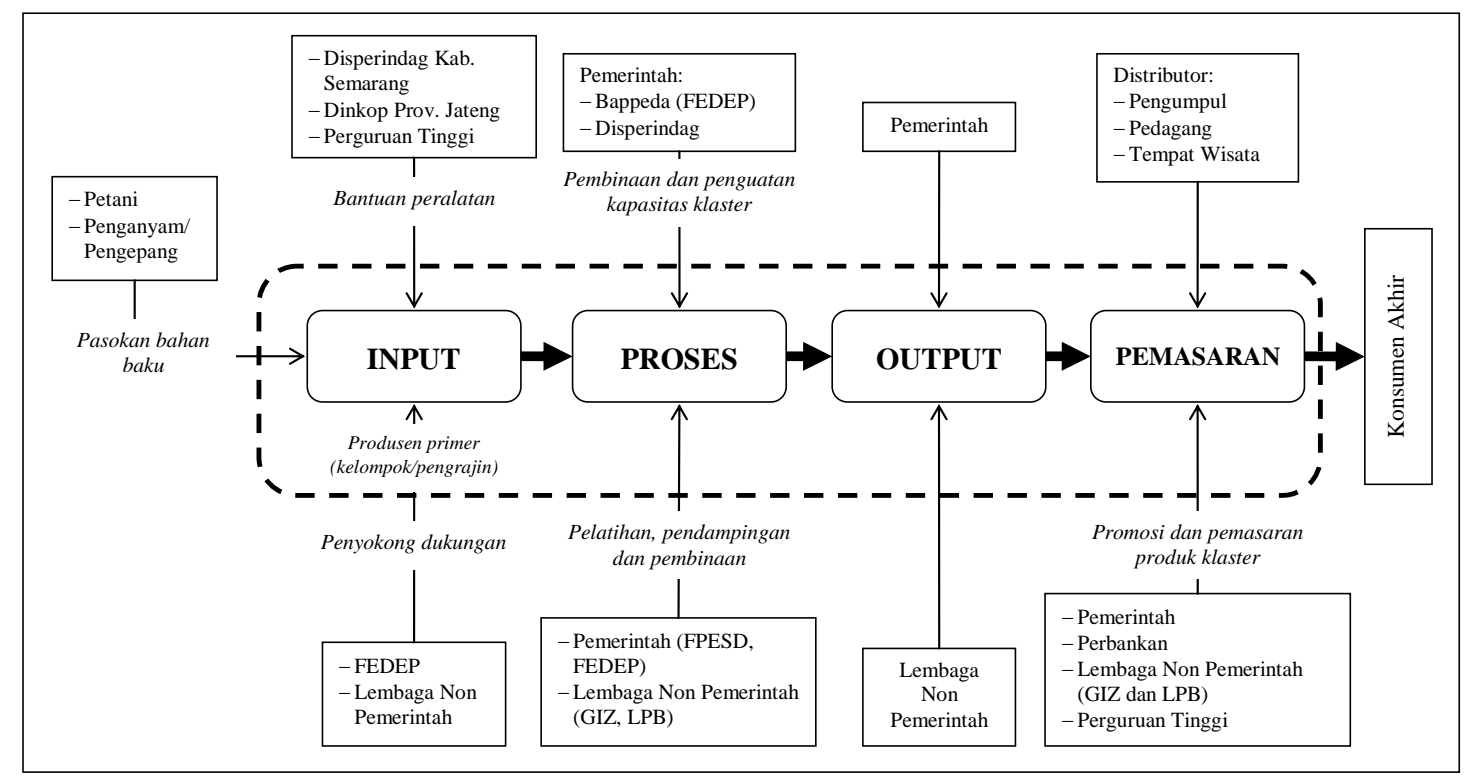

Sumber : Hasil Analisis, 2016

Gambar 1. Pemangku Kepentingan dalam Klaster Enceng Gondok di Kecamatan Banyubiru

Seluruh pemangku kepentingan menjadi pilar penting dalam pelaksanaan suatu kegiatan pembangunan, sehingga setiap pemangku kepentingan harus memiliki kesamaan 
persepsi, jalinan komitmen, keputusan kolektif, dan sinergi aktivitas dalam menunjang pelaksanaan program/kegiatan yang akan dicapai (Iqbal, 2007). Masing-masing pemangku kepentingan memiliki keterlibatan yang berbeda dalam setiap kegiatan klaster. Kegiatan ataupun peran yang dijalankan setiap pemangku kepentingan menyesuaikan pada lingkup peran yang akan dilakukan. Meskipun antara satu pemangku kepentingan dan pemangku kepentingan lainnya memiliki lingkup peran yang berbeda, namun pada dasarnya peran yang dijalankan bersifat saling mendukung satu sama lain sesuai kebijakan dan arahan pengembangan klaster.

\section{Analisis Penilaian Efektivitas Peran Pemangku Kepentingan dalam Klaster Enceng Gondok Kecamatan Banyubiru}

Keberhasilan pengembangan klaster tidak terlepas dari seluruh pemangku kepentingan yang terlibat di dalamnya. Masing-masing pemangku kepentingan memiliki peranan dan kepentingan yang berbeda sesuai dengan lingkup dan kapasitas. Secara umum peran pemangku kepentingan dalam pengembangan klaster (IKM) di antaranya pengembangan dalam hal produksi dan pemasaran, fasilitasi keuangan, pengembangan sumber daya dan pengembangan teknologi (Agustina, Soeaidy, \& Ribawanto, 2010). Namun demikian, peranan yang dilakukan pemangku kepentingan dalam setiap klaster dapat berbeda satu sama lain menyesuaikan pada kondisi dan kebutuhan klaster.

Berikut adalah peranan atau kegiatan pemangku kepentingan dalam Klaster Enceng Gondok di Kecamatan Banyubiru, Kabupaten Semarang (lihat Gambar 1). Berdasarkan hasil penilaian terhadap efektivitas peran pemangku kepentingan, secara keseluruhan pemangku kepentingan yang terlibat dalam Klaster Enceng Gondok memiliki peran yang dinilai cukup efektif bagi pelaku usaha dalam klaster meskipun terdapat beberapa kekurangan dan kegiatan-kegiatan yang dinilai kurang efektif karena tidak memberikan manfaat dan kurang sesuai dengan kebutuhan klaster. Namun peran dan keterlibatan para pemangku kepentingan di atas telah memberikan pengaruh yang berarti bagi klaster. Dari Gambar 1 tersebut dapat dilihat bahwa lembaga nonpemerintah memiliki intensitas keterlibatan yang paling dominan jika dibandingkan dengan pemangku kepentingan lain yang terlibat dalam Klaster Enceng Gondok terutama pemerintah. Hal ini dipengaruhi oleh faktor waktu keterlibatan lembaga terkait dalam klaster dikarenakan adanya waktu kontrak yang membatasi lamanya keterlibatan lembaga tersebut di dalam klaster. Berbeda dengan lembaga nonpemerintah, keterlibatan pemerintah tidak dilakukan secara rutin ataupun intensif seperti halnya lembaga nonpemerintah dikarenakan biasanya pelaksanaan kegiatan oleh pemerintah dapat dilakukan dalam jangka waktu satu tahun sekali atau dalam waktu tertentu sesuai dengan kebutuhan klaster. Meski demikian pelaksanaan kegiatan untuk pengembangan klaster dilakukan secara fokus dan berkesinambungan selama klaster menjadi binaan pemerintah, maka pemerintah akan senantiasa terlibat dalam Klaster Enceng Gondok tanpa ada pembatasan waktu tertentu.

\section{Analisis Peran Pemangku Kepentingan dalam Pengembangan Klaster Enceng Gondok}

Peran yang dilakukan oleh setiap pemangku kepentingan yang terlibat dalam Klaster Enceng Gondok hampir merata dalam setiap tahapan di sistem produksi mulai dari input produksi hingga pemasaran produk klaster. Namun peran pemangku kepentingan di dalam tahap input produksi merupakan peranan yang paling dominan atau banyak dilakukan kepada Klaster Enceng Gondok, hal ini dikarenakan permasalahan yang dihadapi pengrajin lebih banyak terjadi dalam input produksi dibandingkan permasalahan di tahap proses dan pemasaran meskipun permasalahan pemasaran merupakan masalah utama yang dihadapi pelaku usaha di Klaster Enceng Gondok. Keberadaan pemangku kepentingan di Klaster 
Enceng Gondok untuk membantu menyelesaikan permasalahan yang terjadi di sistem produksi klaster memberikan pengaruh positif bagi pelaku usaha terutama untuk meningkatkan produktivitas dan pemasaran produk klaster. Hal ini ditunjukkan dengan adanya perubahan kondisi sebelum (permasalahan) dan setelah adanya intervensi atau peranan terjadi peningkatan kondisi klaster yang lebih baik, baik dalam hal produksi, pemasaran maupun manajemen.

Tabel 3. Efektivitas Kinerja Klaster dari Peranan Pemangku Kepentingan dalam Klaster Enceng Gondok

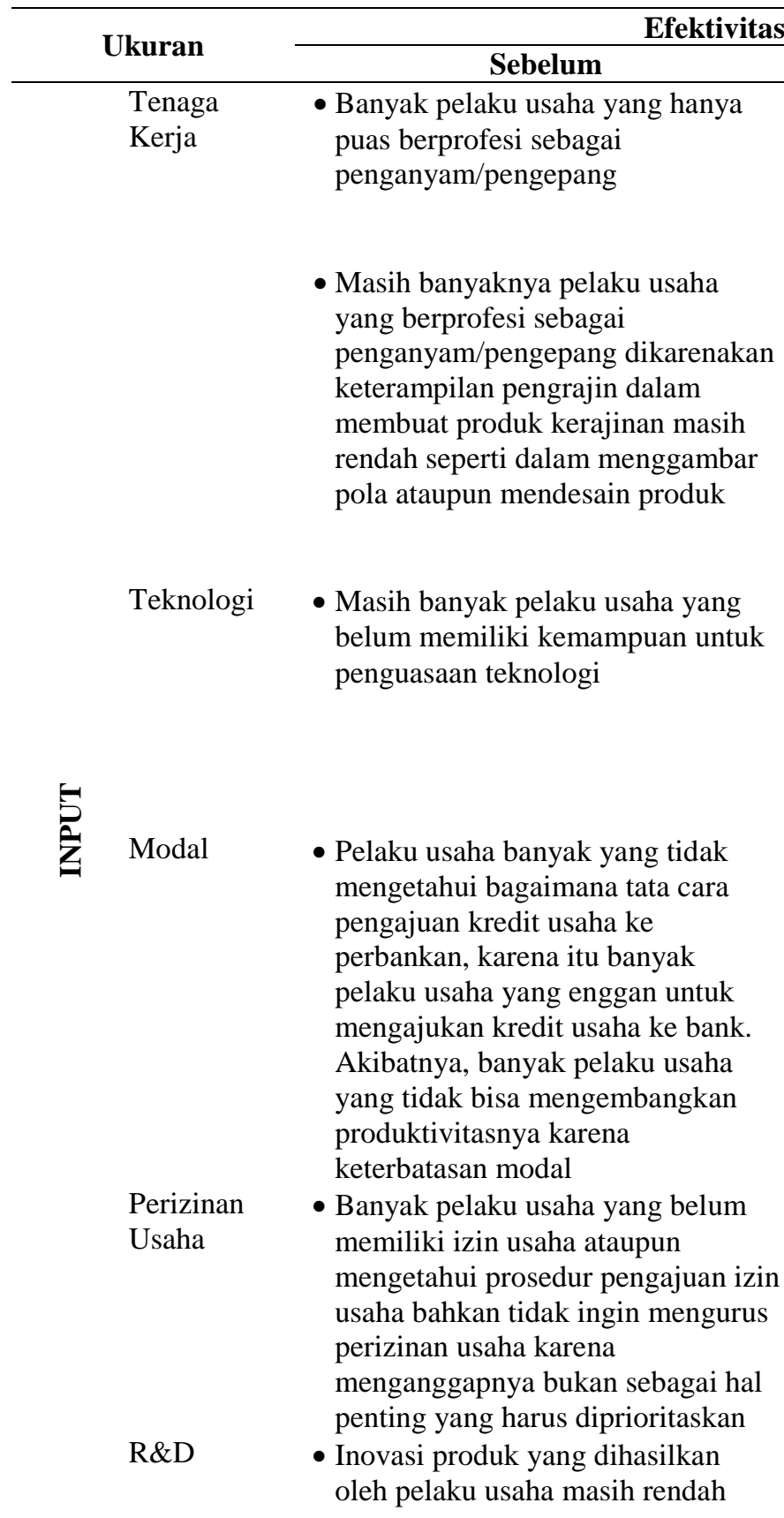




\begin{tabular}{|c|c|c|c|}
\hline & \multirow{2}{*}{ Ukuran } & \multicolumn{2}{|c|}{ Efektivitas Kinerja Klaster } \\
\hline & & Sebelum & Sesudah \\
\hline \multirow{3}{*}{ 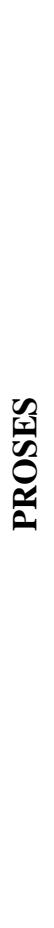 } & $\begin{array}{l}\text { Penggunaan } \\
\text { Alat Untuk } \\
\text { Efisiensi } \\
\text { Produksi }\end{array}$ & $\begin{array}{l}\text { - Peralatan milik klaster yang dapat } \\
\text { digunakan oleh pelaku usaha untuk } \\
\text { menunjang aktivitasnya dalam } \\
\text { jumlah yang sangat terbatas, } \\
\text { sedangkan belum semua pelaku } \\
\text { usaha memiliki peralatan sendiri } \\
\text { yang dapat digunakan untuk } \\
\text { produksinya }\end{array}$ & $\begin{array}{l}\text { - Terdapat bantuan peralatan produksi } \\
\text { kepada klaster yang yang dapat } \\
\text { digunakan oleh pelaku usaha yang } \\
\text { tidak/belum memiliki peralatan sendiri } \\
\text { meskipun pemakaiannya masih secara } \\
\text { bergantian, tetapi sangat membantu } \\
\text { dalam mempercepat proses produksi } \\
\text { kerajinan }\end{array}$ \\
\hline & $\begin{array}{l}\text { Manajemen } \\
\text { Usaha }\end{array}$ & $\begin{array}{l}\text { - Masih banyak pelaku usaha yang } \\
\text { belum memiliki kemampuan } \\
\text { manajemen yang baik, hal ini dapat } \\
\text { dilihat dari masih banyaknya pelaku } \\
\text { usaha yang tidak melakukan } \\
\text { pencatatan keuangan usaha yang } \\
\text { dijalankannya yang menjadi bagian } \\
\text { penting untuk memantau } \\
\text { perkembangan usahanya (untung } \\
\text { dan rugi) }\end{array}$ & $\begin{array}{l}\text { - Pelaku usaha mulai menyadari dan } \\
\text { melakukan pembukuan (pencatatan } \\
\text { keuangan) usahanya meskipun masih } \\
\text { sederhana. Dengan demikian pelaku } \\
\text { usaha dapat mengetahui keuntungan } \\
\text { dan perkembangan usahanya sendiri } \\
\text { - Dalam menjalankan usahanya, pelaku } \\
\text { usaha selalu memperhatikan aspek } \\
\text { kebersihan dan kerapihan dalam } \\
\text { menghasilkan suatu produk }\end{array}$ \\
\hline & & $\begin{array}{l}\text { - Informasi yang diperoleh oleh } \\
\text { pelaku usaha untuk pengembangan } \\
\text { usahanya berasal dari pertemuan } \\
\text { yang dilakukan secara rutin }\end{array}$ & $\begin{array}{l}\text { Lebih banyak informasi yang dapat } \\
\text { diakses dan pengetahuan yang } \\
\text { diperoleh oleh pelaku usaha (klaster) } \\
\text { yang kemudian saling berbagi di antara } \\
\text { pelaku usaha }\end{array}$ \\
\hline \multirow[b]{4}{*}{ 葛 } & Produk & $\begin{array}{l}\text { - Masih rendahnya perhatian } \\
\text { produsen terhadap pentingnya hak } \\
\text { paten }\end{array}$ & $\begin{array}{l}\text { - Pengetahuan pelaku usaha mengenai } \\
\text { hak paten menjadi semakin baik namun } \\
\text { belum terlihat adanya peningkatan } \\
\text { pelaku usaha yang mengurus hak paten }\end{array}$ \\
\hline & & $\begin{array}{l}\text { - Masih rendahnya keragaman } \\
\text { produk kerajinan }\end{array}$ & $\begin{array}{l}\text { - Pengetahuan pengrajin mengenai } \\
\text { desain produk semakin meningkat, hal } \\
\text { ini kemudian berdampak pada } \\
\text { meningkatnya keragaman produk yang } \\
\text { dihasilkan oleh pengrajin }\end{array}$ \\
\hline & & $\begin{array}{l}\text { - Masih rendahnya pengetahuan } \\
\text { produsen terhadap pentingnya } \\
\text { perlindungan konsumen terhadap } \\
\text { produk }\end{array}$ & $\begin{array}{l}\text { - Pengetahuan dan wawasan mengenai } \\
\text { pelaku usaha terkait pentingnya Standar } \\
\text { Nasional Indonesia (SNI) bagi produk } \\
\text { kerajinan menjadi semakin baik }\end{array}$ \\
\hline & & $\begin{array}{l}\text { - Masih banyaknya produsen yang } \\
\text { tidak melakukan pengemasan } \\
\text { produk yang dihasilkan dan belum } \\
\text { memiliki branding }\end{array}$ & $\begin{array}{l}\text { - Kini pelaku usaha sudah mulai } \\
\text { melakukan pengemasan secara baik } \\
\text { terhadap produknya meskipun masih } \\
\text { dalam pengemasan yang sederhana, hal } \\
\text { ini menunjukkan kesadaran dan } \\
\text { perbaikan pelaku usaha dari yang } \\
\text { semula produk tanpa kemasan menjadi } \\
\text { produk kemasan sederhana } \\
\text { - Setelah memiliki branding (merek) } \\
\text { produk klaster, produk klaster memiliki } \\
\text { identitas yang membedakannya dengan } \\
\text { produk kerajinan sejenis dari wilayah } \\
\text { lain sehingga lebih dikenal oleh } \\
\text { masyarakat sebagai produk kerajinan } \\
\text { khas dari wilayah Kecamatan } \\
\text { Banyubiru }\end{array}$ \\
\hline
\end{tabular}




\section{Lanjutan Tabe/ 3}

\begin{tabular}{|c|c|c|c|}
\hline \multirow{2}{*}{\multicolumn{2}{|c|}{ Ukuran }} & \multicolumn{2}{|c|}{ Efektivitas Kinerja Klaster } \\
\hline & & & Sesudah \\
\hline \multirow{15}{*}{ 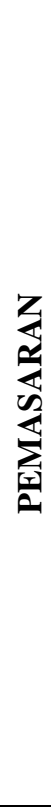 } & \multirow{15}{*}{$\begin{array}{l}\text { Strategi } \\
\text { Pemasaran }\end{array}$} & \multirow{9}{*}{$\begin{array}{l}\text { Pelaku usaha kesulitan dalam } \\
\text { memasarkan produknya karena } \\
\text { pelaku usaha tidak tahu harus ke } \\
\text { mana produk tersebut dijual. } \\
\text { (Pelaku usaha terus melakukan } \\
\text { produksi namun tidak tahu } \\
\text { memikirkan bagaimana pemasaran } \\
\text { yang harus dilakukan pasca } \\
\text { produksi) }\end{array}$} & \multirow{9}{*}{$\begin{array}{l}\text { - Setelah mengikuti berbagai pameran } \\
\text { dan promosi dengan brosur serta } \\
\text { pemasaran melalui situs laman produk } \\
\text { Klaster Enceng Gondok dapat lebih } \\
\text { dikenal secara luas sebagai produk } \\
\text { unggulan dari Kecamatan Banyubiru, } \\
\text { sehingga lebih banyak konsumen } \\
\text { tertarik untuk membeli atau memesan } \\
\text { produk kerajinan enceng gondok dari } \\
\text { Banyubiru. Semakin luas pemasaran } \\
\text { maka semakin banyak konsumen yang } \\
\text { dapat dijaring sehingga akan } \\
\text { meningkatkan keuntungan bagi pelaku } \\
\text { usaha }\end{array}$} \\
\hline & & & \\
\hline & & & \\
\hline & & & \\
\hline & & & \\
\hline & & & \\
\hline & & & \\
\hline & & & \\
\hline & & & \\
\hline & & \multirow{6}{*}{$\begin{array}{l}\text { - Usaha kerajinan pada generasi } \\
\text { pertama mampu mencapai } \\
\text { pemasaran hingga ekspor ke luar } \\
\text { negeri, namun usaha kerajinan yang } \\
\text { tengah berkembang saat ini belum } \\
\text { dapat melakukan eskpor }\end{array}$} & - Pelaku usaha mulai berupaya untuk \\
\hline & & & meningkatkan pemasarannya hingga \\
\hline & & & ekspor dengan mengikuti berbagai \\
\hline & & & sosialisasi dan informasi berkenaan \\
\hline & & & dengan ekspor dari pemangku \\
\hline & & & kepentingan terkait \\
\hline
\end{tabular}

Sumber : Hasil Analisis, 2016

- Usaha kerajinan pada generasi pertama mampu mencapai pemasaran hingga ekspor ke lua tengah berkembang saat ini belum dapat melakukan eskpor
- Setelah mengikuti berbagai pameran Klaster Enceng Gondok dapat lebih dikenal secara luas sebagai produk unggulan dari Kecamatan Banyubiru, sehingga lebih banyak konsumen memesa Banyubiru. Semakin luas pemasaran maka semakin banyak konsumen yang dapat dijaring sehingga akan usaha

Pelaku usaha mulai berupaya untuk meningkatkan pemasarannya hingga ekspor dengan mengikuti berbagai dengan ekspor dari pemangku kepentingan terkait

Berdasarkan analisis terhadap tingkat kepentingan dan pengaruh pemangku kepentingan terhadap klaster, maka diketahui pemangku kepentingan dalam Klaster Enceng Gondok dapat dikelompokkan dalam dua kategori yakni key player (terdiri dari kelompok pemerintah, kelompok lembaga nonpemerintah (GIZ dan LPB Semarang serta kelompok pelaku usaha) dan crowd (terdiri dari kelompok lembaga pembiayaan, kelompok perguruan tinggi dan Yayasan Dompet Dhuafa). Key player merupakan kategori pemangku kepentingan yang memiliki tingkat kepentingan dan pengaruh yang sama-sama besar bagi Klaster Enceng Gondok, sementara crowd merupakan kategori pemangku kepentingan yang memiliki tingkat kepentingan dan pengaruh yang sama-sama kecil bagi Klaster Enceng Gondok.

Pelaksanaan peran masing-masing pemangku kepentingan tidak dapat berjalan tanpa adanya komunikasi, koordinasi dan kerja sama tidak hanya di antara pelaku usaha (klaster) tetapi juga antara pelaku usaha dan pemangku kepentingan lainnya. Herr \& Muzira (2009) menyatakan bahwa pemangku kepentingan dibedakan menjadi pemangku kepentingan privat dan publik. Dalam Klaster Enceng Gondok, yang bertindak sebagai pemangku kepentingan privat adalah pelaku usaha (petani, penganyam/pengepang dan pengrajin) yang berperan sebagai penggerak utama kegiatan-kegiatan dalam sistem produksi mulai dari pengadaan bahan baku hingga pemasaran. Dalam menjalankan sistem produksi tersebut, pelaku usaha baik dalam satu kelompok maupun antarkelompok saling menjalin hubungan yang baik dan bekerja sama satu sama lain. Hubungan (relasi) dan kerja sama yang telah terjalin di antara pelaku usaha didukung tingkat kepercayaan yang tinggi sesama produsen kemudian melahirkan tindakan bersama dalam bentuk kolektivitas dalam menjalankan sistem produksi kerajinan enceng gondok. Meski demikian kolektivitas dalam Klaster Enceng Gondok belum terjadi secara keseluruhan dalam sistem produksi, sehingga nilai tambah belum dapat tercipta sepenuhnya dalam klaster.

Pengembangan Klaster Enceng Gondok tidak terlepas dari peran pemangku kepentingan publik yang terlibat di dalamnya meliputi pemerintah, lembaga pembiayaan (perbankan), lembaga nonpemerintah dan perguruan tinggi. Membangun hubungan (komunikasi) dan kerja sama yang baik antarpemangku kepentingan publik yang terlibat 
dalam klaster dilakukan melalui dialog sosial. Di dalam Klaster Enceng Gondok, dialog sosial yaitu intervensi-intervensi dari setiap pemangku kepentingan yang diartikan sebagai pelayanan yang dilakukan oleh pemangku kepentingan kepada pelaku usaha atau klaster. Dari beragam intervensi yang telah dilakukan oleh pemangku kepentingan yang terlibat dalam Klaster Enceng Gondok, lembaga nonpemerintah merupakan lembaga yang memiliki intervensi paling tinggi atau dominan dibandingkan dengan pemangku kepentingan lain, yang artinya bahwa lembaga nonpemerintah memberikan paling banyak pelayanan kepada pelaku usaha klaster baik pelayanan dalam hal produksi, pemasaran maupun manajemen. Pembagian intervensi dari setiap pemangku kepentingan pada pengembangan sistem pasar di Klaster Enceng Gondok hampir merata di setiap tahapan pengembangan sistem pasar, namun lembaga nonpemerintah dalam Klaster Enceng Gondok memiliki peranan/intervensi yang lebih dominan di masing-masing tahapan sistem produksi dalam Klaster Enceng Gondok. Dengan demikian pemangku kepentingan lebih berperan dominan dalam pengembangan inti usaha Klaster Enceng Gondok dibandingkan sebagai fungsi penunjang.

Peranan yang telah dilakukan masing-masing pemangku kepentingan di dalam klaster memberikan pengaruh positif bagi klaster terutama dalam pengembangan rantai nilai (sistem produksi) usaha dalam klaster, sehingga membuat pelaku usaha menjadi lebih mampu untuk menghadapi persaingan dan tantangan di pasar yang lebih besar.

a)

Efficiency System

- Efisiensi produksi dalam Klaster Enceng Gondok dapat dilihat dari produktivitas yang meningkat karena proses pengerjaan produksi lebih cepat dengan adanya bantuan peralatan dari pemerintah dan perguruan tinggi, kemudahan dalam mengakses modal usaha karena adanya sosialisasi dan pendampingan dalam pengajuan kredit usaha oleh lembaga perbankan dan nonpemerintah, peningkatan kewirausahaan dan kemampuan pelaku usaha dalam penguasaan teknologi informasi dengan adanya pelatihan teknologi informasi dari pemangku kepentingan yang terlibat dalam Klaster Enceng Gondok, serta adanya kemudahan akses dan aliran informasi bagi pelaku usaha klaster.

- Efisiensi dalam pemasaran ditunjukkan dengan strategi pemasaran menjadi lebih baik sehingga volume (nilai) penjualan semakin meningkat dan jangkauan pasar (pemasaran) menjadi semakin luas dengan fasilitasi pemasaran dari seluruh pemangku kepentingan baik melalui pameran maupun pemasaran daring melalui situs laman.

- Efisiensi dalam manajemen atau pengelolaan usaha karena pengetahuan dan ketrampilan (teknis dan manajemen) pelaku usaha semakin baik dan meningkat dengan adanya pelatihan manajemen dari lembaga nonpemerintah.

b) Product Quality

Peningkatan dan perbaikan (upgrading) teknologi dan kualitas produk merupakan salah satu langkah strategis yang harus dilakukan oleh pelaku usaha dalam kelompok klaster untuk pengembangan ke depannya (Marijan, 2005). Dalam usaha kerajinan enceng gondok, kualitas produk klaster meningkat diiringi dengan kesadaran pelaku usaha untuk menjaga kualitas produk sehingga tetap mampu bersaing di pasaran, terbukti secara kualitas produk kerajinan enceng gondok dari Kecamatan Banyubiru (Kabupaten Semarang) lebih unggul daripada kerajinan sejenis dari wilayah lain. Untuk menjaga kualitas produk yang tetap unggul, pemangku kepentingan dalam Klaster Enceng Gondok melakukan beberapa peran dalam rangka memberikan pengetahuan atau wawasan kepada pelaku usaha menyangkut kualitas produk, di antaranya pelatihan 5R (Ringkas, Rapi, Resik, Rawat, Rajin), sosialisasi Standar Nasional Indonesia (SNI), pelatihan pengemasan produk dan pembuatan branding (merek) produk klaster. Upaya yang dilakukan oleh pemangku 
kepentingan dalam klaster terutama lembaga nonpemerintah melalui berbagai pelatihan yang dilaksanakan tidak hanya meningkatkan kemampuan dan ketrampilan pelaku usaha tetapi juga meningkatkan daya saing produk dengan membantu pelaku klaster untuk dapat menghasilkan produk yang berkualitas dan berdaya saing tinggi (Karsidi, 2001).

\section{c) Product Differentiation}

Diferensiasi hasil produksi yang dihasilkan pelaku usaha menjadi salah satu faktor penting yang mempengaruhi eksistensi produk dalam pasar. Terkait dengan diferensiasi produk, hal yang perlu diperhatikan adalah kemampuan inovasi pelaku usaha untuk dapat mempertahankan posisi bersaing produk yang dihasilkannya. Kemampuan inovasi berkorelasi positif terhadap posisi bersaing karena semakin tinggi kemampuan inovasi pelaku usaha akan berpengaruh pada posisi bersaing dalam pasar yang juga semakin kuat (Fitanto, 2009). Kemampuan inovasi salah satunya dapat dilihat melalui variasi atau jenis produk yang dihasilkan oleh pelaku usaha. Variasi produk dalam Klaster Enceng Gondok mengalami peningkatan, dari yang semula hanya 3-4 jenis produk, kini sudah menghasilkan 28 jenis produk dengan berbagai ukuran (produk menjadi lebih inovatif). Adapun peran yang dilakukan pemangku kepentingan kaitannya dalam diferensiasi atau keragaman produk di Klaster Enceng Gondok antara lain pelatihan teknik anyaman dasar, pembinaan dan pelatihan pengembangan produk, pengembangan inovasi produk oleh perguruan tinggi, melakukan kunjungan ke wilayah lain (studi banding), pengembangan desain dan variasi produk, serta sosialisasi hak paten.

\section{d) Social and Environment Standards}

Pencemaran di Rawa Pening akibat limbah akar dan daun yang ditinggalkan oleh petani dapat diminimalkan apabila terdapat inovasi untuk pemanfaatan akar dan daun, selain pemanfaatan batangnya sebagai bahan kerajinan, sehingga dengan demikian dapat memberikan nilai tambah bagi pelaku usaha.

\section{e) Business Environment}

Kondisi lingkungan usaha di Klaster Enceng Gondok menjadi kondusif karena tidak ada persaingan yang tidak sehat di antara sesama pelaku usaha karena pembagian produksi yang jelas pada setiap kelompok di Klaster Enceng Gondok. Lingkungan usaha di klaster juga sangat dipengaruhi peraturan/kebijakan yang ditetapkan pemerintah sebagai regulator seperti salah satunya perizinan usaha. Pemerintah sebagai pemegang kekuasaan di daerah memiliki pengaruh dalam pengembangan klaster karena pemerintah memiliki kekuasaan dalam menentukan aturan-aturan yang nantinya dapat mempengaruhi perkembangan klaster, salah satunya dalam menentukan aturan mengenai kondisi iklim atau lingkungan usaha (Murti, 2010).

Untuk mewujudkan pengembangan klaster yang efektif diketahui bahwa diperlukan kerja sama di antara pemangku kepentingan (publik dan privat) di setiap kegiatan usaha di sepanjang rantai nilai, tidak hanya dalam rangka mencapai kebutuhan pasar tetapi juga mencapai keberhasilan pengembangan klaster. Pemangku kepentingan publik dalam pengembangan Klaster Enceng Gondok turut berperan dalam memberikan dukungan dalam bentuk kegiatan pelatihan, pendampingan maupun pembinaan. Sementara pemangku kepentingan privat (pelaku Klaster Enceng Gondok) menjalankan peranan penting sebagai pelaksana inti dari aktivitas rantai nilai (input, proses, ouput dan pemasaran). Membangun relasi (hubungan) dan kerja sama di antara pemangku kepentingan dalam klaster, baik pemangku kepentingan publik maupun privat, menjadi salah satu hal penting untuk menjaga kelangsungan dan kemajuan klaster. 


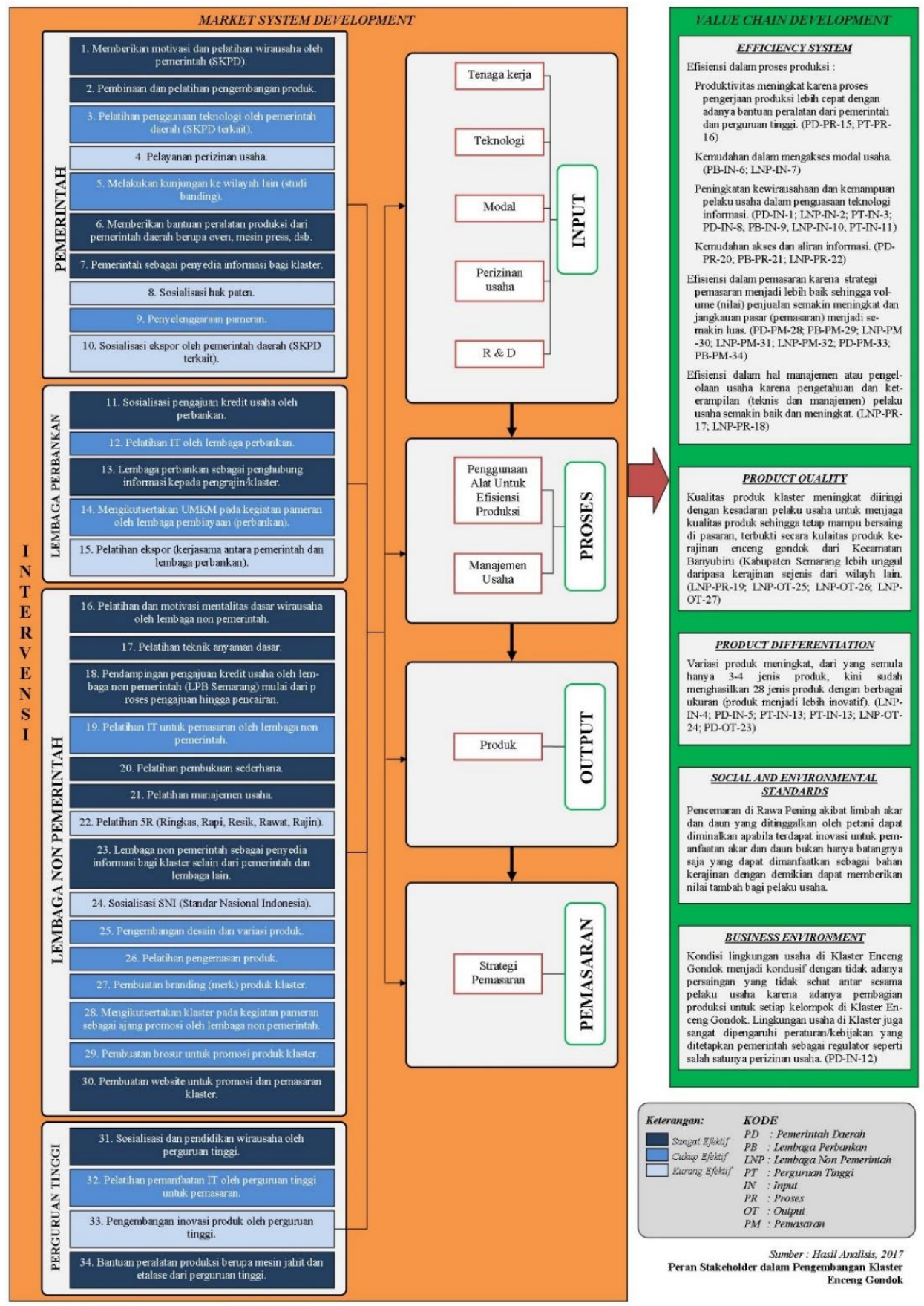

Sumber : Hasil Analisis, 2016

\section{Gambar 2. Peran Pemangku Kepentingan dalam Pengembangan Klaster Enceng Gondok di Kecamatan Banyubiru}

\section{Kesimpulan}

Secara keseluruhan pemangku kepentingan yang terlibat dalam klaster memiliki peran yang dinilai cukup efektif bagi Klaster Enceng Gondok meskipun terdapat beberapa peran yang dinilai kurang efektif dan bermanfaat bagi klaster. Peranan yang memiliki nilai efektivitas tertinggi adalah peran yang dijalankan pemerintah dalam tahap input produksi terkait dengan pemberian bantuan peralatan produksi untuk menunjang dan meningkatkan 
produktivitas pelaku klaster. Sementara itu peranan yang memiliki nilai efektivitas paling rendah adalah peranan yang dijalankan oleh lembaga nonpemerintah pada tahap output produksi terkait pemberian sosialiasi mengenai SNI karena tidak sesuai dengan kebutuhan klaster. Ditinjau dari peranan-peranan yang telah dijalankan setiap pemangku kepentingan dalam Klaster Enceng Gondok, lembaga nonpemerintah memiliki peranan yang paling banyak dan dominan dalam klaster, sedangkan lembaga pembiayaan (perbankan) dan lembaga pendidikan dan penelitian merupakan pemangku kepentingan dengan peranan yang relatif sedikit dan tidak intensif dibandingkan pemangku kepentingan lain.

Berdasarkan peranan pemangku kepentingan dalam Klaster Enceng Gondok tersebut, juga dapat diketahui bahwa pemerintah dan lembaga penunjang klaster lainnya sebagai pemangku kepentingan publik memiliki peran dalam memfasilitasi kebutuhan klaster, yaitu melakukan dialog sosial antara klaster dan pemerintah maupun lembaga pendukung klaster lainnya, dan mencari penyelesaian terhadap permasalahan yang terjadi di dalam klaster. Sementara itu pelaku usaha klaster sebagai pemangku kepentingan privat lebih berperan dalam menjalankan hubungan di antara pelaku usaha yang lebih bersifat bisnis, serta melaksanakan atau menggerakkan sistem produksi dalam klaster sebagai bagian dari rantai nilai/inti usaha klaster sesuai fungsi-fungsi pembentuk rantai nilai yang dapat memberikan nilai tambah dan meningkatkan daya saing klaster.

Pengembangan Klaster Enceng Gondok dengan pendekatan pengembangan rantai nilai adalah bagaimana membangun hubungan komunikasi dan kerja sama yang baik di antara pemangku kepentingan yang terlibat dalam klaster, tidak hanya pemangku kepentingan privat (klaster) tetapi juga di antara pemangku kepentingan publik dalam menyelesaikan berbagai permasalahan yang dihadapi klaster. Adanya keterlibatan dan peranan pemangku kepentingan tidak dapat dipungkiri juga memberikan pengaruh positif bagi pelaku usaha dalam klaster maupun perkembangan klaster. Semakin besar dan efektif keterlibatan pemangku kepentingan dalam Klaster Enceng Gondok berbanding lurus dengan perkembangan klaster, terutama dalam pengembangan inti usaha (sistem produksi) klaster dan penyelesaian permasalahan klaster. Peranan pemangku kepentingan dalam klaster menjadi faktor penting dan diperlukan bagi suatu klaster usaha untuk menjadi berkembang dan mandiri yang tanggap dalam menghadapi segala permasalahan dan tantangan ke depannya. Namun bukan berarti peranan pemangku kepentingan menjadi satu-satunya faktor penting untuk mencapai perkembangan klaster secara keseluruhan, tetap diperlukan faktor-faktor lain yang mempengaruhi perkembangan klaster seperti kewirausahaan, kemampuan dan ketrampilan individu, inovasi serta faktor pencapaian efisiensi kolektif dalam klaster yang tidak kalah penting untuk pengembangan klaster.

\section{Rekomendasi}

Beberapa rekomendasi yang dapat diberikan kepada pihak-pihak yang terlibat di dalam klaster dalam rangka pengembangan klaster yang lebih maju dan berdaya saing antara lain:

\section{- $\quad$ Rekomendasi bagi Pemerintah}

Perlu adanya pemantauan dan evaluasi dari pemerintah terhadap kondisi dan perkembangan klaster serta keterlibatan pemangku kepentingan lain dalam Klaster Enceng Gondok. Peran pemerintah sebagai fasilitator perlu lebih dioptimalkan terutama dalam melakukan pendampingan kepada pelaku usaha dan memfasilitasi dialog yang menjembatani komunikasi dan kerja sama antara pelaku usaha dan pemerintah. Selain itu, perlu adanya infrastruktur yang dapat menunjang aktivitas klaster seperti koperasi untuk pendanaan klaster serta penyediaan showroom sebagai media promosi kolektif bagi pelaku usaha dalam klaster. Pemasaran yang diintegrasikan dengan tempat-tempat wisata di Banyubiru dan sekitarnya dapat menjadi salah satu langkah untuk meningkatkan 


\section{Peran Pemangku Kepentingan dalam Pengembangan Klaster...}

pemasaran produk klaster. Sebagai regulator, pemerintah perlu membuat regulasi atau kebijakan untuk melindungi keberlangsungan usaha kerajinan enceng gondok di Kabupaten Semarang.

- $\quad$ Rekomendasi bagi Lembaga Pembiayaan (Perbankan)

Terkait dengan peran perbankan dalam pembiayaan klaster, kegiatan pelatihan hendaknya dapat dilakukan secara menyeluruh dengan melibatkan seluruh pengrajin yang tergabung dalam Klaster Enceng Gondok terutama dalam pemberian informasi dan sosialisasi mengenai prosedur pengajuan pinjaman (kredit) usaha kepada pelaku usaha. Selain itu, pembinaan dan pendampingan yang dilakukan lembaga pembiayaan (perbankan) terkait dengan peningkatan ekspor kerajinan enceng gondok diharapkan dapat dilakukan secara lebih intensif kepada klaster dan terus memberikan dorongan dan dukungan kepada pelaku usaha untuk pengembangan usahanya. Untuk ke depannya diharapkan keterlibatan lembaga pembiayaan (perbankan) dapat lebih ditingkatkan, tidak hanya dalam pembiayaan tetapi juga kegiatan-kegiatan lainnya dalam rangka pengembangan klaster seperti manajemen ataupun pemasaran.

- $\quad$ Rekomendasi bagi Lembaga Nonpemerintah

Pelaksanaan kegiatan pelatihan bagi pelaku usaha harus disesuaikan atau difokuskan pada aspek atau hal-hal yang menjadi permasalahan dan kebutuhan klaster sehingga hasil yang diperoleh dapat bermanfaat bagi pengrajin dan pelaku klaster lainnya.

- $\quad$ Rekomendasi bagi Lembaga Pendidikan dan Penelitian

Peran lembaga pendidikan dan penelitian (perguruan tinggi) dalam research and development $(\mathrm{R} \& \mathrm{D})$, khususnya pengembangan inovasi klaster perlu ditingkatkan, karena dengan mengembangkan inovasi, klaster memiliki kemampuan bersaing dengan produk kerajinan dari wilayah lain.

- $\quad$ Rekomendasi bagi Pelaku Klaster

Dari kegiatan-kegiatan pelatihan yang diselenggarakan baik oleh pemerintah, lembaga pembiayaan (perbankan), lembaga nonpemerintah serta perguruan tinggi hendaknya pelaku usaha dapat menyerap pembelajaran yang ada dan mengaplikasikannya dalam kegiatan klaster untuk meningkatkan nilai tambah bagi klaster. Pelaku usaha hendaknya ikut memantau atau mengatasi bagaimana kinerja dan peranan yang dilakukan para pemangku kepentingan yang terlibat dalam klaster agar hasil dan manfaat yang diperoleh klaster menjadi lebih maksimal.

\section{Daftar Pustaka}

Agustina, R., Soeaidy, M. S., \& Ribawanto, H. (2010). Peran pemangku kepentingan dalam meningkatkan perekonomian lokal melalui industri kecil menengah (IKM) (Studi pada Dinas Perindustrian, Perdagangan, Pertambangan, dan Energi Kota Kediri). Jurnal Administrasi Publik, 2(5), 844-850. Retrieved from http://administrasipublik.studentjournal.ub.ac.id/index.php/jap/article/view/475.

Bank Indonesia. (2015). Kajian Identifikasi Indikator Sukses Klaster. Jakarta: Bank Indonesia. Retrieved from http://www.bi.go.id/id/umkm/penelitian/nasional/kajian/Pages/Kajian-Identifikasi-Indikator-SuksesKlaster.aspx.

Creswell, J. W. (2010). Research Design. Pendekatan Kualitatif, Kuantitatif dan Mixed (Fawaid. A, Trans). In S.Z. Qudsi (Eds). Yogyakarta: Pustaka Pelajar. (Original work published 1997).

Djamhari, C. (2006). Faktor-faktor yang mempengaruhi perkembangan sentra UKM menjadi klaster dinamis. Infokop, (Nomor 29), 83-91.

Fitanto, B. (2009). Analisis omset dan posisi bersaing pada klaster usaha kecil menengah (UKM) sepatu Kota Mojokerto. Journal of Indonesian Applied Economics, 3(1), 23-36. Retrieved from 
http://jiae.ub.ac.id/index.php/jiae/article/view/137/106.

Ginting, C., \& Prabatmodjo, H. (2015). Kondisi kemitraan nelayan Kawasan Pesisir Kecamatan Pantai Labu sebagai basis pengembangan ekonomi lokal. Jurnal Perencanaan Wilayah dan Kota, 4(2), 251-259.

Herr, M. L., \& Muzira, T. J. (2009). Value chain development for decent work: A guide for development practitioners, government and private sector initiatives. International Labour Office. Switzerland. Retrieved from www.oit.org/wcmsp5/groups/public/---ed_emp/---emp.../wcms_116170.pdf.

Hornby, A. S. (1995). Oxford Advanced Learner's Dictionary of Current English. Oxford: Oxford University Press.

Humphrey, J., \& Schmitz, H. (1996). The Triple C Approach to local industrial policy. World Development, 24(12), 1859-1877. doi: 10.1016/S0305-750X(96)00083-6.

Iqbal, M. (2007). Analisis peran pemangku kepentingan dan implementasinya dalam pembangunan pertanian. Jurnal Litbang Pertanian, 26(3), 89-99. Retrieved from http://pustaka.litbang.pertanian.go.id/publikasi/p3263071.pdf.

Kaplinsky, R., \& Morris, M. (2004). A Handbook for Value Chain Research.. Sussex: Institute of Development Studies.

Karsidi, R. (2001). Peran sosial LSM dalam era otonomi daerah. Disampaikan dalam Seminar Peran LSM dalam Otonomi Daerah dan Accountability LSM terhadap Rakyat, LBPH-YBKS dan PLSGG-FISIP UNS, Solo 12 April 2001. Retrieved from https://digilib.uns.ac.id/dokumen/detail/1873/PERAN-SOSIAL-LSMDALAM-ERA-OTONOMI-DAERAH.

Marijan, K. (2005). Mengembangkan industri kecil menengah melalui pendekatan kluster. INSAN, 73), 216225. Retrieved

from https://www.google.co.id/url?sa=t\&rct=j\&q=\&esrc=s\&source=web\&cd=1\&cad=rja\&uact=8\&ved=0a hUKEwjKiMCH1abWAhVDsI8KHQZNC50QFgglMAA\&url=http\%253A\%252F\%252Fwww.journal.unai r.ac.id\%252FfilerPDF\%252F02\%252520-

\%252520Mengembangkan\%252520Industri\%252520Kecil\%252520Menengah\%252520Melalui\%25.

Murti, A. I. (2010). Peran pemerintah daerah dalam pengembangan klaster batik Laweyan. Tata Loka, 12(1), 5562.

Oktavia, S., \& Saharuddin. (2013). Hubungan peran pemangku kepentingan dengan partisipasi masyarakat dalam program agropolitan Desa Karacak Kecamatan Leuwiliang Kabupaten Bogor. Sodality: Jurnal Sosiologi Pedesaan, 1(3), 231-246. doi: 10.22500/sodality.v1i3.9407.

Rahma, H. (2012). Acuan Penerapan Pengembangan Ekonomi Lokal untuk Kota dan Kabupaten. Jakarta. Retrieved from ciptakarya.pu.go.id/usdrp/.../Buku PEL 2012 Final.pdf\%0A.

Retnoningrum, R. A. (2011). Pemanfaatan Enceng Gondok Sebagai Produk Kerajinan: Studi Kasus di KUPP Karya Muda "Syarina Production" Desa Kebondowo Kecamatan Banyubiru. Universitas Negeri Semarang. Retrieved from http://lib.unnes.ac.id/11260/1/9045.pdf.

Rinaldy, E. (2007). Rantai Nilai dan Keruangan Komoditas Jeruk Sambas. Universitas Diponegoro. Retrieved from http://eprints.undip.ac.id/7531/.

Schmitz, H. (1995). Collective efficiency: Growth path for small-scale industry. The Journal of Development Studies, 31(4), 529-566. doi: 10.1080/00220389508422377.

Schmitz, H. (1999). Collective efficiency and increasing returns. Cambridge Journal of Economics, 23(4), 465483. doi: $10.1093 / \mathrm{cje} / 23.4 .465$.

Sugiyono. (2015). Metode Penelitian Pendidikan Pendekatan Kuantitatif, Kualitatif dan R\&D. Bandung: Alfabeta.

Sumodiningrat, G. (2000). Pembangunan Ekonomi melalui Pengembangan Pertanian. Jakarta: Bina Rena Pariwara. 